\section{CLASS, GENDER AND THE REPRESENTATION OF PEASANT WOMEN IN VIETNAMESE LITERATURE*}

\author{
Montira Rato**
}

\section{Abstract}

The paper seeks to explore how peasant women are portrayed in Vietnamese literature and tries to highlight that, throughout the development of Modern Vietnamese literature, the way in which peasant women are portrayed is closely related to political agendas and ideological struggles. It also proposes that the construction of peasant women in Vietnamese literature is not only gender-based, but also class-bound. In the period between 1930 and 1945, the victimisation of peasant women was used as a tool to criticise the colonial administration. In the $1945-75$ period, literature took part in mobilising the force of peasant women in the building of a socialist nation. However, post-1975 literature reflected the failure of the Communist government and its Socialist ideology to eradicate the residue of the old values in the country

* This article is based on Chapter 3, 'Peasant Women' in Ph.D. thesis entitled 'Peasants and the countryside is Post-1975 Vietnamese Literature'., SOAS, University of London, 2003.

** Lecturer in Vietnamese Department of Eastern Language, Faculty of Arts, Chulalongkorn University. side, including the patriarchal concepts and the kinship system. The post-war writers use the pictures of unhappy women inthe remote villages to criticise and ridicule the rhetoric and promises of the revolution.

\section{The Emergence of Peasant Women in Vietnamese Literature}

Traditionally, Vietnamese women have been controlled by the Confucian concepts of three submissions and four virtues. The three submissions divide a woman's life into three stages: when she is young, she has to obey her father; when she is married, she has to depend on her husband; and if her husband dies, she will have to listen to her eldest son. The four virtues include, labour-which constitutes skills like cooking, sewing and embroidery, physical appearance, appropriate speech and proper behaviour. However, it is argued that these Confucian doctrines were strictly applied only to upper-class women whereas women from lower classes, especially peasant women, suffered, to a lesser degree, from these Confucian influences.

For example, Arlene Eisen Bergman makes an observation in her study on Vietnamese women that, 'Peasant women were by no means simply sorrowful victims of feudal patriarchy. Their songs expressed their anger and also gave strength to their resistance.'

1 Bergman, Arlene Eisen. Women of Vietnam. Second edition. San Francisco: People Press, 1975.P.35. 
Tran Quoc Vuong also states in his book Truyen Thong Phu Nu Viet Nam (The Tradition of Vietnamese Women) that the peasant family was based on the harmony between husband and wife. He then supports his argument with this proverb; thuan vo thuan chong tat bien Dong cung can (the harmony between husband and wife can dry the Eastern Sea). ${ }^{2}$ It is also generally assumed that working in the rice fields and sometimes earning extra money from being small traders in markets allowed a peasant woman more freedom both inside her household and in the public sphere.

Nevertheless, a different view is proposed by the historian David Marr, who points out that although women in peasant families might not have to endure Confucian norms as much as did upper - and middle-class women, they were not necessarily better off. Young daughters from peasant families were sold as servants, concubines, or prostitutes becauseof family poverty. There were also cases of tenants' wives or daughters being harassed or raped by landowners or mandarins. ${ }^{3}$ Moreover, in a peasant family, the main labour in the rice fields was normally undertaken by women. In spite of the fact that women played a vital role in the family's livelihood, their status both in the family and in society was still lower than that of men. The position of a woman in the

${ }^{2}$ Tran Quoc Vuong.Truyen Thong Phu Nu Viet Nam (The Tradition of Vietnamese Women). Hanoi: NXB (Nha Xuat Ban = Publishing House) Phu Nu, 1972. P. 12.

${ }^{3}$ Marr, David G. Vietnamese Tradition on Trial, 1920-1945. Los Angeles: University of California Press, 1984. P. 197. traditional Vietnamese village very much depended on the status of her husband, as Jamieson describes:

The village status hierarchy was formally restricted to men only. Strictly speaking, women were not even members of the village. A woman's status level, in the sense of the way people treated her, depended upon her age, her reputation and her background. But basically, a woman took her husband's status. Women were, in fact, commonly addressed and referred to by their husband's status, title, or role. ${ }^{4}$

According to Marr, it was not until the 1920 s that the debate on women's rights apparently began in Vietnam. A number of magazines and journals during this period, such as Nam Phong (Southern Ethos), were dedicated to the issue of women's rights. However, the focus of these magazines was mainly restricted to the interests of upper-class women. ${ }^{5}$ Also, it can be observed that the emphasis on women's issues in this period reflected the decline of Confucianism and the increasing influence of Western ideas of egalitarianism and individualism. In literature, the individual pursuit of happiness is contrasted with Confucian doctrine, which emphasises

\footnotetext{
${ }^{4}$ Jamieson, Neil L., 'The Traditional Village in Vietnam' in The Vietnam Forum, no.7. New Haven: Yale Southeast Asian Studies, 1986. P.100.

${ }^{5}$ Marr, David. Vietnamese Tradition on Trial, 1920-1945. P. 202.
} 
the duty of a person towards his or her family and society. Arranged marriage is strongly opposed, whereas freedom in love and marriage is promoted. The novel To Tam [1925] by Hoang Ngoc Phach and the works by Tu Luc Van Doan (The Self-Reliant Literary Group) published between 1933-1936, such as the novel Doan Tuyet (Breaking the Tie) [1935] by Nhat Linh, portray middle and upper-class women who were torn apart by love and filial piety. ${ }^{6}$ However, the bourgeois movement to modernise Vietnam and the demand for the individual pursuit of happiness against Confucian ethics did not give much attention to peasant women. Women from the lower classes, such as peasants and workers, are almost absent from the works by urban-based writers.

It was the Indochinese Communist Party that eagerly put problems of lower-class women to the fore during the $1930 \mathrm{~s}$. It was clearly stated in the report from the plenary session of the Party held in October, 1930 that:

The party must free women from bourgeois ideas and eliminate the illusion of equality between the sexes expanded in bourgeois theories. At the same time, it must enable women to participate in the revolutionary struggles of the workers and peasants. This is an important task. For if women do not take part in these struggles, they can

${ }^{6}$ For further discussion on these works, see chapter 3 in Jamieson, Neil L. Understanding Vietnam. Berkeley: University of California Press, 1995. never emancipate themselves. So, it is necessary to fight the feudalists or religious customs and superstitions in their way, give women workers and peasants inventive political education, arouse their class consciousness and enable them to join the organisations of the working class. Political work must be carried out not only in towns but also in the countryside, among the poor peasants and all working women...To rally the women of all social strata, women's organisation should unite them in the struggle for their own rights and for their complete emancipation. These organisations shall enrol working women, workers' wives, women small traders, and all those who cannot join the workers' and peasants' organisations. ${ }^{7}$ (sic.)

The influence of Marxist ideology on the emancipation of women is shown in the articles by Phan Khoi and Nguyen Thi Chinh published in the women's magazine Phu Nu Tan Van numbering 160 (21-07-1932) and number 162 (04-08-1932), respectively. Phan Khoi comments that the only way to emancipate women is to change people's nhan sanh quan (way of thinking). Nguyen Thi Chinh argues that women's liberation is related to luat tien hoa cua lich su (historical development) and nen

\footnotetext{
${ }^{7}$ Mai Thi Tu and Le Thi Nham Tuyet. Women in Vietnam. Hanoi: Foreign Languages Publishing House, 1978. Pp. 116117.
} 
mong kinh te (economic foundation). Therefore, to liberate women it is necessary not only to change their way of thinking, but also to reduce their working hours and increase their wages. By doing so, there would be a consciousness of women's rights among workingclass women who, unlike women from the middle-class, were still not aware of the ongoing debate. ${ }^{8}$ However, it was not until the mid-1930s that working-class and peasant women had a chance to participate in the women's movement. Under the liberal policies of the Popular Front government in France (1936-1938), the Indochinese Communist Party launched a programme called 'chi em binh dan' (common sisters). Its main issue was to demand equal pay and eight weeks of paid maternity leave. The programme focused on the masses of female workers and peasants. In fact, the belief that the emancipation of women could be accomplished by the introduction of large-scale industry, reflected in Nguyen Thi Chinh's article, is ideologically inherited from Engels' work, The Origin of the Family, Private

${ }^{8}$ These two article were later printed in Thanh Lang (ed.). 13 Nam Tranh Luan Van Hoc (1932-1945) (13 Years of Literary Debate). Volume 3. Ho Chi Minh city: NXB Van Hoc, 1995. 134-145.

${ }^{9}$ In his writings on the woman's issue, Ho Chi Minh made several references to Engels' ideas, and explicitly revealed his admiration to this Marxist philosopher. For example, see Ho Chi Minh. Ho Chu Tich voi Van De Phu Nu (President Ho Chi Minh and The Woman Question). Hanoi: NXB $\mathrm{Phu} \mathrm{Nu}, 1960$. In fact, the emancipation of women, especially those from lower classes,
Property and the State [1884]. This book played an important role in making policies and forming ideologies on gender and family in Communist states, Vietnam included. ${ }^{9}$ In his well-known work, Engels explains that the subordination of women is related to material inequality and the ownership of private property. He argues further that the abolition of the family-based economy, and the provision of social services covering domestic chores and childcare would free women from gender inequality. This was because the large-scale industry system would break down the kinshipand patriarchal family system, which ideologically has had a significant influence on men and women alike. As he postulates:

The emancipation of woman will only be possible when woman can take part in production on a large, social scale, and domestic work no longer claims anything but an insignificant amount of her time. And only now has that become possible through modern large-scale industry, which does not merely

received considerable attention from Communist leaders elsewhere as well as in Vietnam. For instance, in the book, The Development of Capitalism in Russia, Lenin describes how peasant women and workingclass women were exploited. But he stated that the large-scale industry and working in factories would help emancipate women from the patriarchal system. In China, MaoTse-Tung regarded women as the most oppressed people in society, as he wrote in 'Report on an Investigation into the Peasant Movement of Hunan, 1927'. 
permit the employment of female labour over a wide range, but positively demand it, while it also tendstoward ending private domestic labour by changing it more and more into a public industry. ${ }^{10}$

Engels' analysis of gender inequality from the standpoint of historical materialism provides the insight that the oppression of women is complex. It also helps us to understand how historical, political, social and economic conditions determine the unequal relationship between men and women, who are the agents of production and reproduction. As Engels points out, the oppression of women is also related to the structures of the mode of production and social class, which are also main factors in the oppression of women. Thus, the oppression of women should not simply be ascribed to male chauvinism. In the same way, it is not always true that all women are sisters. In Vietnamese feudal society, poor peasants, men and women alike, were equally oppressed by both male and female members of the landowning class.

Engels' explanation of the relation between gender inequality and the ownership of private property was well received in Vietnam. For example, Vu Ngoc Phan, a scholar and an expert in Vietnamese folk literature, explains that peasant women traditionally had to listen to their fathers, husbands, male siblings or even their sons because

10 Engels, Frederick. The Origin of the Family, Private Property and the State. London: Lawrence\&Wishart, 1972. P. 221. women had no right to the ownership of property, and only men were entitled to inherit the family's land and property. ${ }^{11}$ The following folksong can support Vu Ngoc Phan's argument and illustrate how an older unmarried peasant girl feels about the issue of inheritance as the years pass:

The star of the third watch is above my head (11 pm-1am)old unmarried girl

Yet, I'm still staying at home to enrich my father

When my father gets rich, he does not divide his wealth evenly

And as a girl what share do you think I get? ${ }^{12}$

Thus, the rise in the status of peasant women and the emergence of peasant women in literature were due to the influence of Marxist ideology and Communist movements in the 1930s. By the late 1930s, urban-based middle-class writers began to feel that their own class was corrupt, and that their lives were trivial and meaningless. They turned to the countryside and peasants for a place to escape from turmoil in the corrupted city. The countryside was considered as a source of morality. Therefore, it is not

\footnotetext{
"Vu Ngoc Phan, "Nhung Tieg Phan Khang cua Phu Nu Nong Thon trong Dan Ca Viet Nam' (Rural Women's Voice of Resistance in Folk Songs) in Tap San Nghien Cuu Van Su Dia, no. 6, 1955. P. 41.

${ }^{12}$ Ngo Vinh Long. Vietnamese Women in Society and Revolution: The French Colonial Period. Vietnamese Resource centre: Massachusetts, 1974. P. 8.
} 
surprising that the members of Tu Luc Van Doan (The Self-Reliant Literary Group) criticised the manners and attitudes of bourgeois women and romanticised peasant women for their self-sacrifice and diligence. For example, in the short story Hai Ve Dep (Two Beauties) [1936], Nhat Linh shows that city girls, Dung, Lan and Tuyet, were living a dissipated life. Their existence was pointless. They might look beautiful, but their beauty came from their make-up and clothes. Compared to the simple but genuine beauty of the rural women, the beauty of urban women was fake and superficial.

At the same time, the Realist and revolutionary literature became dominant in Vietnamese literary circles and public debates.Realist and revolutionary writers attacked the colonial regime for its oppressive policies towards local people, and criticised the feudal system as backward and outdated. A new type of literature turned its hope for the future to peasants, with the expectation that the salvation of the nation would be accomplished by the masses. However, when writing about peasants, writers normally referred to male peasants, whereas peasant women played only a minor role and were normally included in the stories as the wives,

${ }^{13}$ Gender bias can be observed through Nguyen Cong Hoan's works. He was strongly against the idea that women should be free from familial piety and have the right to choose their own partner. For example, in his novel o Giao Minh (Miss Minh, the School Teacher) [1936], which was written to respond to the novel Doan Tuyet (Breaking the Tie) by Nhat Linh, Nguyen Cong daughters or lovers of the male protagonists. In the literary works written during the period of 1930-1945, it is common for peasant women to be described as stupid and credulous, and they were often depicted as the victims of exploitation and rape by feudal landlords or men from the city.

Some male writers were unable to avoid the influence of Confucian bias against women. It is not difficult to find traces of gender-biased ideology influenced by the Confucian concept of patriarchy in their works. For instance, the wellknown writer Nguyen Cong Hoan might have to accept that peasants were a main force for the revolution, but he could not wholeheartedly admire them because of their backwardness and unrefined manners. In his works, male peasants are described as ignorant and superstitious, but peasant women are depicted as being even worse. For example, in his well-known novel, Buoc Duong Cung (Impasse) [1939], the wife of Pha, the protagonist, is portrayed as stupid and gullible, and the author did not bother giving her a name. She did not believe that having an injection could protect her from epidemic diseases. As the author clearly pointed out, her death is due to her ignorance and superstition. ${ }^{13}$

The oppression of peasant women came a topic that received considerable

Hoan conservatively pointed out that a bewomen should try to persevere and learn how to be a good wife and daughter-in-law instead of following the Western model and demanding freedom. The discussion of this novel can be found in Jamieson, Neil L. Understanding Vietnam. Berkeley: University of California Press, 1995. Pp. 144-154. 
attention from petty-bourgeois and middle-class male writers in the late 1930s. However, their ultimate goal was, in fact, to condemn the corruption of local officials and criticise the policies of the colonial government, such as the tax system. The historian, Hue-Tam Ho Tai, observes that writing by male writers about the oppression of women during the 1920s and 1930s was a means of expressing their frustration about the political situation in colonial society and criticism against colonial administration. As she explains:

Gender acted as a coded language of debating a whole range of issues without overstepping the limits imposed on public discourse by colonial censorship. The French rhetoric of empire which represented France as the mother country, the Governor-General as a father figure, and the colonial people as children of various stages of immaturity met its match in the Vietnamese literary practice at commenting on the human condition through the device of female characters. ${ }^{14}$

In 1941, the Women's Association for National Salvation was founded. It aimed to unite Vietnamese women from all classes in order to fight against the Japanese and the French troops. In 1946

\footnotetext{
${ }^{14}$ Hue-Tam Ho Tai. Radicalism and the Origins of the Vietnamese Revolution. Cambridge, MA : Harvard University Press, 1992. P. 90.

15 Mai Thi Tu and Le Thi Nham Tuyet. Women in Vietnam. Pp. 324-325.
}

there was the foundation of the Vietnam Women's Union, which is still active to the present day. These women's organisations share two main purposes: to support the revolution and to defend women's rights. ${ }^{15}$ Therefore, the movement for gender equality and the struggle for national independence are closely linked. The liberation of women was largely a political end. According to Marr, the policy of gender equality and the contribution of women were important weapons employed by the Party in the post- 1945 period. ${ }^{16}$ Literature, which is also regarded as a political weapon by Vietnamese leaders ${ }^{17}$, unavoidably took part in these women's movement campaigns, as will be discussed in the following section.

\section{Peasant Women in Wartime Literature}

In the thirty years of wartime literature (1945-1975), the portrayal of peasant women altered dramatically from the previous period: namely, from being victims of economic oppression in a colonial society women became instead the agents of production and political activities. This change in the representation of peasant women was due to the Communist government's determination to pacify the South and to establish

${ }^{16}$ Marr, David. Vietnamese Tradition on Trial, 1920-1945. P. 192.

${ }^{17}$ For example, Pham Van Dong pointed out, 'In Ideological struggle, art is really a sharp weapon because its effect is very deep and lasts very long.' From To Quoc Ta, Nhan Dan Ta, Su Nghiep Ta va Nguoi Nghe Si (our Nation, Our People, Our Cause and the Artists). Hanoi: NXB Van Hoc, 1969. P. 99. 
agricultural collectivisation, as a part of the process of Socialist development. As will be shown in the following paragraphs, peasant women were often portrayed as warriors and labourers on collective farms.

\section{Peasant Women as Guerrilla Fighters}

The Communist government in the North,under the policy of liberating the South and unifying the whole of Vietnam, sent troops and revolutionaries to propagate Communist ideology in the Southern areas, and not only men but also a number of women were recruited to join the movement, notably the famous long-hair army. ${ }^{18}$ It is estimated that there were 840,000 women guerrillas in North Vietnam in 1952, and 140,000 female fighters in the South in $1950 .{ }^{19}$ Most of them came from peasant families.

The female fighters are vividly portrayed in a number of novels, short stories and reportages, notably in the works by the revolutionary writer Nguyen Thi. He worked as a revolutionary cadre in the Southern region, and worked closely with peasant women in this area. Many of his characters are

\footnotetext{
${ }^{18}$ For more detail, see Taylor, Sandra C. Vietnamese Women at War: Fighting for Ho ChÝ Minh and the Revolution. Kansas, University Press of Kansas, 1999.

${ }^{19} \mathrm{Mai}$ Thi Tu, 'The Vietnamese Woman Yesterday and Today' in Michael Klein (ed.). The Vietnam era: Media and Popular Culture in the US and Vietnam. London and Massachusetts: Pluto Press, 1990. P. 193.
}

based on his experiences and encounters with peasant women in the South, especially in the areas occupied by foreign troops. His novels and short stories repeatedly show how patriotism and responsibility to the nation can turn an ordinary peasant girl into an effective guerrilla fighter.

For example, the storylines of his wellknown short stories; Nguoi Me Cam Sung (Armed Mother) [1965] and Me Vang Nha (Mother Is Not Home) [1966] are based on the real story of a patriotic Vietnamese peasant woman, Nguyen Thi Ut. The writer praised Nguyen Thi Ut for being brave and patriotic. As emphasised in both short stories, Nguyen Thi Ut loved her husband and children no less than did other women, but still she regarded the national cause as the first priority. She joined the guerrillas and fought energetically, even when she was pregnant.

Through the character, Nguyen Thi Ut, the author draws a triangular connection between class struggle, women's libera tion, and national independence. Nguyen Thi Ut is born in a poor peasant family and is, at the age of eight, sold to a landowning peasant, Ham Gioi. She has to work as a servant and is badly treated. One day, due to hunger she steals a piece of meat. The landlady beats her brutally and asks her to return the meat. As she has already swallowed the meat, the cruel woman makes Nguyen Thi Ut vomit. Nguyen Thi Ut is freed when the liberation forces come to the village. Then, Nguyen Thi Ut joins the guerrillas. As a young girl, she begins to realise that women are prone to sexual harassment by the soldiers of 
the foreign troops and the Southern regime. Nguyen Thi Ut soon understands that fighting for national freedom is necessary because this would guarantee that she would not have to tolerate oppression from the landowners and harassment from the enemy.

According to Tran Trong Dang Dan, a literary critic, the characterisation of Nguyen Thi Ut exemplifies the qualities of Vietnamese women exalted by Ho Chi Minh. During the war against the American troops, Ho Chi Minh used four words to describe the characteristics of Vietnamese women: anh hung (heroic), bat khuat (indomitable), trung hau (faithful), and dam dang (responsible). ${ }^{20}$ Whether or not Nguyen Thi was aware of Ho Chi Minh's description of the ideal woman and should be considered as a genuine writer or merely as war propagandist, he contributed a great deal in conveying the sacrifice and heroism of peasant women.

\section{Peasant Women as Agricultural Labourers}

After the land reform programme and agricultural collectivisation were introduced in North Vietnam in the 1950s, novelists and short story writers emphasised the role of peasant women in agricultural production. It is evident that the collective farms had to rely on women's labour whilst almost all the

${ }^{20}$ Tran Trong Dang Dan. Gop May Dong vao Van Hoc (The Contribution to Literature). Hanoi: NXB Khoa Hoc Xa Hoi, 1999. P. 246. men in the village were recruited to fight in the war. It is reckoned that, during the war, women made up 80-90 per cent of the members of the agricultural cooperatives. ${ }^{21}$ The importance of peasant women for the new agricultural system was clearly stressed by the Vietnamese leader Le Duan:

Ours being mainly an agricultural economy, the main task of the drive for socialist transformation in the immediate future is to turn our backward agriculture into a co-operat-ivized, and subsequently, mechanised and modern agriculture. Who are the labourers that directly carry out the socialist revolution in the countryside? They are the poor and middle peasants, half of whom are women. It may be said that our women peasants are shouldering a bigger workload than men. A great number of them have thus taken a direct part in the socialist revolution now unfolding in the countryside. ${ }^{22}$

Therefore, peasant women unsurprisingly became a main focus in literature. A number of short stories and novels, notably those written after agricultural collectivisation was introduced into the countryside, stress that it was necessary for peasant women to take part in economic and political activities. Two short stories by Ngo

\footnotetext{
${ }^{21}$ Ibid., p. 195.

${ }^{22}$ Le Duan, 'We Must View the Women's Question from a Class Standpoint'. P.113.
} 
Ngoc Boi, Chi Ca Phay (Madame Bright Skin) [1961] and Chi Than (Madame Than) [1970] are good examples of this literary trend.

Ngo Ngoc Boi wrote Chi Ca Phay (Madame Bright Skin) in order to awaken a social consciousness among peasant women. Chi Ca Phay is described as a typical Vietnamese peasant woman: hard working, thrifty and conservative. Chi Ca Phay, a widow, never intends to remarry but a number of men are interested in her. She tries hard to stay un married and takes good care of her only son. However, the author does not consider her behaviour admirable. Instead, he indicates that she is ideologically influenced by Confucian ideas. According to the Confucian norms, a widow is not encouraged to remarry and is even regarded as property of her late husband's family. Chi Ca Phay is also criticised for her attempt to arrange a marriage for her 11-year-old son. Through the viewpoint of $\mathrm{Cu}$ Hiep, a respectable old man in the village, Chi $\mathrm{Ca}$ Phay does not need to worry about her son or prepare anything for his future because he is now a child of the collective. So, his future will be secure. For the author, Chi Ca Phay and other female peasants should change their ideas about the upbringing of children and try to be a part of the collective.

In depicting Chi $\mathrm{Ca}$ Phay, the author endeavoured to point out the conservative characteristics of Vietnamese peasant women, whereas the character Chi Than is to contrast with Chi Ca Phay and represent an ideal model for Vietnamese peasant women. Chi Than represented the image of peasant woman that the government wanted to promote: namely, she understands the purpose of the revolution and how it is necessary for women to share revolutionary tasks. Unlike other women in the village who moan when their husbands leave to fight in the war, Chi Than not only stays calm, but also helps remind other women that they have important tasks to do while their husbands are away, including increasing the production of the co-operative.

Ngo Ngoc Boi was not the only writer who underlined the conservative mentality of peasant women, especially in terms of love and marriage. A similar theme is also found in the novel, Di Buoc Nua (Take Another Step) [1960], by Nguyen The Phuong. The author criticises the conservative notion that did not allow a widowed woman to remarry, but which required her to stay and work for the family of her late husband. The story reveals the difficult life of Hoan, a widow with two childreri. Her mother-in-law has sympathy for Hoan, but she does not want Hoan to do anything that would go against traditional practices. The narrator shows that one problem of achieving gender equality is that gender prejudices are deeply rooted in women's mentality. Towards the end of the novel, Nguyen The Phuong emphasises that it was Communist cadres and the co-operative system that brought happiness to peasant women and emancipated them from conservative ideas preventing them from 'di buoc nua', or 'remarrying'.

The similarity between these two stories is not a coincidence. Both authors reflect the Communist government's 
attempt to improve the social status of women. After the Communists took control of the northern part of the country, they introduced two main policies that were believed to be perfect solutions for the emancipation of women, especially those from the peasantry. The first policy was to change some legislative issues on marriage and the family, and the second was agricultural collectivisation. The law on marriage and family, passed in 1960, stated that polygamy was illegal. Ho Chi Minh himself also paid attention to this issue. As he commented:

Failing to free women means failing to liberate half of humanity. Failing to free women means that the building of socialism is half completed... The law on marriage aims at freeing women, that is, liberating half of society. As women are emancipated, we must eradicate feudal and bourgeois ideology in men. ${ }^{23}$

However, changing men's ideology, as Ho Chi Minh suggested, was not simple, as reflected in the collection of short stories, Bong Hoa Sung (Water Lily) [1967] by the writer Vu Thi Thuong. She uses the water lily as a metaphor for the beauty of Vietnamese peasant women. At first glance, people may not consider the water lily to be beautiful, however, if they take time to look at it more care fully, they will see that this kind of flower is no less beautiful than others. Moreover, its beauty contains modesty

${ }^{23}$ Quoted in Bergman, Arlene Eisen. Women of Vietnam. P. 215. and serenity. Similar to Ngo Ngoc Boi, Vu Thi Thuong served the national cause and responded to the government's policy on rural development in her writing. However, her works express a better understanding of women in the countryside. For instance, in the short story Tu Moi Can Nha Nhu The (From Each House Like That), published in the same collection, the theme is to call for women's support in taking charge in political and social tasks. The story argues that peasant women who did not join the revolution, or remained passive, did so not because they were conservative or selfish,but because they did not have enough confidence. The author suggests that peasant women need to be encouraged and assured that they could work and contribute to society as well as men.

As reflected in her short stories, Vu Thi Thuong often asserts that government programmes in the 1960 s, such as $\mathrm{Ba}$ dam dang or the 'Three Responsibilities' ${ }^{24}$ and 'Three Ensures' 25 move ments, were helping to improve the status of peasant women in village

${ }^{24}$ It required women to take part in the production of collective farms and other activities while men went to the battlefield. Women were also expected to take charge of all family affairs, and support the fighting against foreign invaders. See more in Mai Thi Tu, and Le Thi Nham Tuyet. Women in Vietnam. P. 258.

${ }^{25}$ It included; ensure timely planting, ensure good techniques and ensure cultivation in accordance with the plan. See more in Glorious Daughters of Vietnam. 2 volumes. Hanoi: The Vietnam women's Union, 1975. P. 27. 
society. Owing to these movements, more women were being elected as leaders of local communities. However, a main problem as regards women taking control of local organisations was from the social attitudes towards women. ${ }^{26}$ In general, people did not believe that women could be as good leaders as the men. For example, in the short story Chung Toi...(We...), the old man Gang is pleased when his daughter gets elected as the chairman of a co-operative. But, at the same time, he is worried that, as a girl, she will be unable to manage the co-operative and gain respect from people in the village. Similarly, in the short story Cau Chuyen Xay Ra Khong Tranh Khoi (Inevitable Conflict) [1966], Vu Thi Thuong shows us how a peasant woman is struggling to be accepted as a leader of a village com munity. Through the character Mui, who is appointed as the chairperson of a cooperative, the author reveals that it is difficult for a woman to hold political office, not because of her lack of ability but because of the way she is perceived. For Mui, it is even worse because her confidence is undermined by her own husband. He is proud of his wife, but is still concerned that she might not be capable of completing the task by herself and will need his assistance.

${ }^{26}$ This problem was recognised by the Premier Pham Van Dong. Follow is the quotation from his speech in February 1967:

Though we are a socialist country, a heroic nation with an advanced and civilised ideology and political regime, we still have many shortcomings concerning women. These are the remnants of old, feudal and backward
At the end of the story, the author points out that a woman who wants to achieve public confidence and acceptance must also confront the patriarchal ideology which prevails in her own family. Like Mui, in order to carry on a political task, she needs to be confident and to fight against old-fashioned ideas and biases, even from her own husband. As Vu Thi Thuong emphasises, it is important for gender prejudice to be solved first at the household level.

Another interesting story, which is based on a similar theme, is Vo Chong Chi Doi Truong (The Unit Leader and Her Husband). People in the village and officials in central administration all agreed that Mrs. Vinh was qualified to be the leader of a production unit. The only reason they did not want her to take the position of leader was because she was a woman. They decided that, in theory, her husband should take the title of unit leader while in practice Mrs. Vinh would do the job for him. Owing to the 'Three Responsibilities' movement promoting the role of women in the village community, Mrs. Vinh was finally

ideas. The struggle against these attitudesnot must occur in both the spheres of culture and ideology. How should we go about eliminating these vestiges? Uncle Ho said recently that in some places women and wives were still badly treated. This is not an isolated phenomenon, but a rather common one unfortunately.

From Pham Van Dong. Some Cultural Problems (speeches). Hanoi: Foreign languages Publishing House, 1981. P. 44.. 
elected as the unit leader. The following conversation shows how women are discriminated against by gender bias in village community:

A man, about 30 years old, suddenly asked:

'Why didn't we elect her as our unit leader since Mr. Bai resigned last time?'

One person answered:

'Probably because at that time she just gave birth to a baby...'

Another person argued:

'No, it was not because of giving birth, but I guess it's because she was sick.'

Mrs. Man, who is wellknown for being outspoken, could not stand these speculations any longer, and had to interrupt the conversation:

'It was not because she gave birth or was ill. It was only because in those days you men discriminated against us women. There was no difference among cadres. You never wanted to vote for us. Just only now with the 'three responsibilities' programme, and also if you don't let women in, who will work in this production unit when men are going to join the army?' 27

The decade of 1960 s, the period of Socialist construction and establishment of collective farms, was generally

${ }^{27}$ Vu Thi Thuong. Vo Chong Chi Doi Truong (The Leader Unit and Her Husband) in Bong Hoa Sung: Tap Truyen Ngan. Hanoi: NXB Van Hoc, 1967. P. 45. celebrated by writers as the first time in Vietnamese history that women from lower classes, in particular from the peasantry, had been given a sense of pride and dignity. The writers highlighted the fact that peasant women had the right to join agricultural co-operatives and were given land and tools. The Communist system of 'work points' also allowed peasant women to earn points and to receive a share from the harvest according to how much work they did. This also enabled them to be a part of the community. They did not have to take their husbands' status or name as they had in previous periods. However, while responding to government policies on rural development and mass mobilisation, literature did not fail to raise an intriguing question as to whether or not agricultural collectivisation and government campaigns on women movements had brought about gender equality in the countryside. As discussed earlier, throughout this period writers argued that Vietnamese peasant women still suffered from the patriarchal concept, and that it was, in fact, never successfully abolished. ${ }^{28}$

Some have concluded that the women's movement in wartime Vietnam was

${ }^{28}$ According to Mai Thi Tu, the policy of promoting women cadres did not fully achieve its goals. She notes that in 1960 1,150 women were elected to the management committees of co-operatives in Hai Duong province. But this number was only 11 per cent of the total membership, whereas the target was 30 per cent. See more in Mai Thi Tu, 'The Vietnamese Woman Yesterday and Today' P. 195. 
geared not towards liberation, but to exploitation. For instance, Stephanie Fahey argues that the Vietnamese leaders regarded the woman question as part of the agenda for national struggle and socialist society. ${ }^{29}$ David Marr mentioned in his book that 'it was often pointed that if all Vietnamese were oppressed to some degree, then Vietnamese woman were the most oppressed of all. ${ }^{30}$ A similar comment was made by another historian, Douglas Pike, who put it bluntly that 'the women were in truth the water buffalo of the Revolution.' ${ }^{31}$ Christine White shares the same view and asserts that '[T]he Leninist route to Women's emancipation

Another example of sexual inequality in agricultural co-operatives is revealed in Tran Thi Van Anh's article, as follows:

In practice, however, cooperative heads assigned work according to their perceptions of workers' abilities. Thus, women were more likely to be assigned traditional women's work, such as transplanting, weeding, manuring, harvesting and animal-breeding. In general, women's work received fewer work points. One workday for transplanting earned ten points, and one workday for fertilising received eight. Men's work earned them more points: one workday for ploughing received twelve points and one workday for a carpenter earned fourteen .

For more information, see Tran Thi Van Anh, 'Women and Rural Land in Vietnam' in Tinker, Irene and Gale Summerfield (eds.). Women's Right in House and Land: China, Laos and Vietnam. London: Lynne Rienner Publishers, 1999. P. 99. by drawing women into productive labour seems a cruel joke, a formula for total exhaustion rather than for liberation. ${ }^{32}$ These comments are by no means overstatements. However, it is difficult to determine categorically whether or not the invention of a stereotype of peasant women in literature contributes to the process of this exploitation. Throughout the period between 1945-1975, literature was subordinated to the political struggle, and the reflection of peasant women in literary works was intended to highlight the importance of socialist construction and economic development in rural areas. The link between the images of peasant women in the literature and the political agenda of nation-state building is evident. Nevertheless, one can say that during the wartime period the contribution of peasant women and realisation of their problems were raised and discussed in literary works to an unprecedented degree. Vietnamese writers took part in the mobilisation of peasant women in the struggle and establishment

\footnotetext{
${ }^{29}$ Fahey, Stephanie, 'Vietnam's Women in the Revolution Era' in Sen, Khrisha and Maila Stivens (eds.). Gender and Power in Affluent Asia. London and New York: Routledge, 1998. P. 225.

${ }^{30}$ Marr, David G. Vietnamese Tradition on Trial, 1920-1945. P.191.

${ }^{31}$ Pike, Douglas. Viet Cong: The Organisation and Techniques of the National Liberation Front of South Vietnam. Massachusetts: The M.I.T Press, 1966. P. 178.

${ }^{32}$ Quoted in Pham Van Bich. The Vietnamese Family in Change: The Case of the Red River Delta. Surrey: Curzon, 1999. P. 64.
} 
of agricultural collectivisation, but their sympathy for peasant women was somehow undeniably real.

\section{Peasant Women in Post-1975 Literature}

This part of the article will focus on the depiction of peasant women depicted in post-1975 literature, and will study the main factors underlining the changes and continuities in the representation of peasant women. An early remark is that the transformation of the socio-political context from wartime into peace had a significant effect on the change in the representation of peasant women in literature. It can be seen in the literary works discussed in the following paragraphs that there is an attempt to de-politicise the depiction of peasant women, while the issues of gender bias are more openly discussed.

What is often reflected in the post-war literary texts is the fact that peasant women in Vietnam are still burdened by social and gender prejudices arising from the Confucian concept of patriarchy. Post-war writers, such as Le Luu, Nguyen Khac Truong and Duong Huong, use their writings to expose the patriarchal, kinship and family systems that are still practised in the rural areas of Vietnam. Through the period of Socialist development, patriarchy might have been challenged, reformed or refined, but it was obviously never abolished. For example, in her research

${ }^{33}$ Barry, Kathleen (ed.). Vietnam's Women in Transition. London: Macmillan Press, 1996. P. 12. on women in Vietnam, Kathleen Barry explains that the failure of the government policy to emancipate women in Vietnam was caused by the fact that it over-simplified the problem. The Vietnamese Communists believed that gender inequality could be solved if men changed their attitudes. However, the problem was never properly resolved and it still occurs in post-war society mainly because 'men, like other privileged groups, do not give up power in the family or anywhere else because they are expected to change their attitudes. ${ }^{33}$

In her interesting work Patriarchy and Socialist Revolution in China, Judith Stacey argues that Socialism cannot emancipate women. In fact, Socialism is rather compatible with a patriarchal gender-biased system. This is because a patriarchal family economy and patriar chal consciousness are important elements in building a Socialist society. ${ }^{34}$ The author describes Chinese society as 'patriarchal socialism' which means 'the socialisation of most, but not all, productive activities in the context of sustained, but reformed, patriarchal authority over women, marriage, and domestic economy'. ${ }^{35}$ This explanation

${ }^{34}$ Stacey, Judith. Patriarchy and Socialist Revolution in China. Berkeley, Los Angeles and London: University of California Press, 1983. Pp. 265-266.

${ }^{35}$ Ibid., p. 217. According the Marxist feminist Michele Barrett, the sociologist Max Weber described the term 'patriarchy' as 'a particular form of household organisation in which the father dominated other members of an extended kinship network and controlled the economic 
can also be applied to the social context of Vietnam. Vietnamese rural society is structured with feudal relations of power in which seniority and filial piety are still significant. In a family, the husband has control and authority over his wife and children. Kathleen Barry describes the relationship in Vietnamese family as follows:

...the family in Vietnam today is charged with feudal relation of power, and is structured around the veneration of elders and filial piety. Family feudalism is a stage in the historical development of the patriarchal family, just beyond slavery, where lord, or in the case of family, husband, holds complete control and authority over the household, whose mem- bers, children and wife, serve him. He may be ruthless or beneficent, but he is not held accountable outside his private fieldom: 'each man's home is his castle' ${ }^{36}$

The family economy system has been restored since new land laws were passed in 1988 and 1993. According to the new laws, land would be allotted to peasant families, and this replaced the work points system, which allowed individuals to earn work points according to the amount of work that he or she was assigned. Although it allowed peas-

production of the household.' See more in Barrett, Michele. Women's Oppression Today: Problems in Marxist Feminist Analysis. London: Verso, 1980. Pp. 10-11.

${ }^{36}$ Barry, Kathleen (ed.). Vietnam's Women in Transition. P. 11. ant families to be more independent from the state, it brought back the old pattern that the husband became the head of family and had the right to make decisions on household business. Moreover, women had a minor role and almost no power in the Vietnam Peasants' Association, one of the largest social organisations in Vietnam. Almost all its members were men because they were given their role as the head of the household. ${ }^{37}$ The family-based system also had an effect on women because the assistance subsidy to women for reproductive activities during the sociali st period was decreased. ${ }^{38}$

In fact, the ideology of patriarchy was still exercised during the period of Socialism (1945-1975). If we look back at the slogans and programmes launched by the Vietnam Women's Union aimed at mobilising women, especially from the lower classes, we can see that women were required to share social responsibility with men rather than to be encouraged to demand complete freedom. To a certain extent, the wartime programmes, such as the "Three Responsibilities', are comparable to the Confucian doctrines of three submissions and four virtues instructing women how they should behave. This is in fact

\footnotetext{
${ }^{37}$ Tran Thi Que, 'Gender Issues in Vietnam's Development' in Norlund, Irene et al. (eds.). Vietnam in a Changing World. Surrey: Curzon, 1995. P. 199.

${ }^{38}$ Tran Thi Van Anh, 'Vietnam' in Tinker, Irene and Gale Summerfield (eds.). Women's Rights in House and Land: China, Laos and Vietnam. London: Lynne Rienner Publishers, 1990. P. 101.
} 
a new way to set a patriarchal standard and impose it on women. Consequently, it can be concluded that patriarchy might have been challenged, but it was never abolished in Vietnamese rural society. Vietnamese peasant women still have to struggle against patriarchal thinking and the kinship system, and this is an enduring theme to be explored, debated and challenged in the post-1975 literary works.

To begin with, let us take a look at the award-winning and best-selling novel Manh Dat Lam Nguoi Nhieu Ma (A Plot of Land With Many People and Ghosts) by Nguyen Khac Truong. Here, it is shown that patriarchal ideology and the kinship system still play an important role in Vietnamese society. Ancestor worship is still commonly practised in Vietnam, especially in rural areas. If the ancestor of one family makes an oath, whatever it is, his children have to follow it and pass it to later generations, mainly through the patri-lineal line. It is generally believed that disasters will occur if a member of the family breaks the family's rule or disobeys the ancestor's order. In this novel, the author tells us how a peasant woman becomes a victim of an ancestor cult conflict and patriarchal concepts.

The story begins with a love triangle. Son, a beautiful girl, had a secret relationship with a married man, Vu Dinh Phuc. Her parents forced her to marry Trinh $\mathrm{Ba}$ Ham, a rich peasant in the village. The Trinh $\mathrm{Ba}$ and Vu Dinh have been enemies for generations, and people from these two families have been competing with each other for political positions in the village. The love triangle between Son, Phuc and Ham increased the hatred between the two families. As the author describes:

The old people said: the conflict caused by marriage and ricefield will take ten thousand years to revenge. This means nothing can make people hate each other longer than conflicts about marriage and land. The Trinh $\mathrm{Ba}$ and Vu Dinh cannot share the same mat because of these two things! In those days, people from the two families fought in the middle of village's pagoda during the village fair. Their forefathers fought because of land and position. The position of village chief is small, but it is about dignity, winning and losing between two families. It also means who will get the heads of chickens and pigs, and who will get the best seat at the village hall. Both sides have been competitive. In the generation of Phuc, it is about love. It is weird that these two families spy and trick each other tirelessly. ${ }^{39}$

After Son marries Ham, she finds no happiness in her life. For Ham, his wife is a reminder that he is inferior to Phuc because Phuc slept with Son before he married her. The conflict of ancestor cults also has an influence on the love relationship between Dao, Ham's

\footnotetext{
${ }^{39}$ Nguyen Khac Truong. Manh Dat Lam Nguoi Nhieu Ma (A Plot of Land with Many People and Ghosts). Hanoi: NXB Hoi Nha Van, 1999. P. 25.
} 
daughter and Tung, a member of the $\mathrm{Vu}$ Dinh family. The Trinh Ba family used Son as a tool to destroy the Vu Dinh. The trick is that the Trinh Ba family accuse Vu Dinh Phuc of having an affair with Son. Ham and his relatives demand that in order to get Phuc, a party cadre, removed from his political position, Son should appear at the meeting of party members and the village committee and indict Phuc of using his position to force her to have an affair with him. Son decides not to comply with this plan because she cannot bear to be humiliated by the rumours and gossipof other villagers. Instead, she chooses to commit suicide to escape the battle between the two families; however, her death does not lessen the antagonism of other villagers. Instead, she chooses to commit suicide to escape the battle between the two families; however, her death does not lessen the antagonism Ham is concerned about the death of Son less than about his image and dignity. He is infuriated by the fact that his rival, Phuc, receives the news of Son's death and reaches her body before him. The excerpt below shows how self-centred and chauvinistic he is:

Trinh $\mathrm{Ba}$ Ham is angry not because of the death of his beautiful wife. It is because he realised that he was always late! Vu Dinh Phuc always comes first and is ahead of him! Even the death of Son, Phuc witnessed before him. ${ }^{40}$

${ }^{40}$ Ibid., pp. 286-287.
This theme is also emphasised in Duong Huong's famous novel, Ben Khong Chong (A Watering Place for Women with No Husband) [1990]. This work shows that the interference of parents in the courtship and marriage of their children remains widely practised and acceptable in the countryside of Vietnam. ${ }^{41}$ In the novel Ben Khong Chong (A Watering Place for Women with No Husband) Nghia and Hanh decide to get married in spite of the disapproval from their families. The conflict between the two families starts when a girl from the Nguyen clan is raped by a man from the Vu clan. The Nguyen vow that they will get revenge and regard the $\mathrm{Vu}$ as their enemy. Although this incident happened long ago and the animosity between members of both sides decreased, the Nguyen are still reluctant to give their blessings to the relationship between Nghia and Hanh. The marriage is strongly opposed by the male members of the Nguyen clan. They consider it is the duty of men to protect the pride of the clan and make sure that the ancestors' instructions are followed. For them, this marriage is humiliating for the clan. The attitude of female members of the Nguyen is milder. In fact, they even have sympathy for Nghia and Hanh, but they are afraid that disobeying the oath of the ancestors would bring about misfortune. Duong Huong argues that it is not the oath or offending the ancestors that can cause disaster for the family, but rather

${ }^{41}$ According to Le Thi, a Vietnamese sociologist, marriages in agricultural society are arranged by parents, and sometimes have to be approved by the whole lineage. See more in Le Thi. The Role of the Family in the Formation of Vietnamese Personality. Hanoi: The Gioi Publishers, 1999. P. 25. 
the dark side of human beings: namely, hatred, anger and jealousy. An old member of the Nguyen family is jealous of Nghia because he is the head of the clan. The old man burns the communal house where the whole clan comes to worship ancestors, and then spreads the rumour that the ancestors punished the clan for allowing Nghia to marry Hanh.

The favouring of boys over girls is also mentioned in Duong Huong's novel, Ben Khong Chong (A Watering Place for Women with No Husband). Nghia's mother arranges for him to divorce Hanh and marry another woman. She is desperate for a grandson who will continue the family line. Interestingly, people in the village, including Hanh herself, tend to believe that it is Hanh's fault for not having a son to carry on the family's line. Nobody asks question about Nghia's possible infertility. When a couple don't have a child, it seems that the wife is the first person to be blamed. It is even the right of her mother-in-law to look for a new wife for her husband.

Duong Huong's novel strives to fight against this bias when the narrator relates how Nghia's injury from fighting in the war caused his infertility. The author includes this detail in order to show that it is not always a woman's fault when she can not have a baby. Also,

\footnotetext{
${ }^{42}$ It is translated from Vietnamese 'Nhat Nam Viet Huu, thap nu viet vo'. Cong Huyen Ton Nu Nha Trang says that these patriarchal concepts are influenced by Confucian teaching. Confucianism was highly favoured during the Le dynasty, but then lost its popularity from the sixteenth century
}

that is not because of the curse or oath of ancestors. In the case of Nghia and Hanh, it is the war that robbed them of their happiness.

A similar theme is also reflected in the controversial novel by Duong Thu Huong, Nhung Thien Duong Mu (Paradise of the Blind) [1988]. As shown in Duong Thu Huong's novel, in a peasant family, Que always has to yield to her younger brother's demands simply because he is the only heir in the family. She is ready to sacrifice everything she has for her brother, even her marriage or the education of her own daughter. She prefers her daughter to starve and live modestly in order that she can spare some money to support her brother and his two sons. This is because of the traditional belief that only a son can carry forward the family's identity and honour. This is not something new, but a continuation of the long tradition of prejudice against women. As is clearly shown in popular sayings: 'one boy you can inscribe a descendent, ten girls you can write nil' and 'when there is but one man, you can call it a presence; but ten women together will be counted as none' ${ }^{42}$ Another well-known

onwards because it was difficult for the ruling class to follow the standards of Confucian precepts. However, Confucianism was restored again in 1802 under the Nguyen Dynasty, and since then patriarchal ideology reasserted itself in Vietnamese society. See more in Cong Huyen Ton Nu Nha Trang, 'The Makings of the National Heroine' in The Vietnam Review (no.1, Autumn-Winter 1996), p.403. 
expression is 'a hundred daughters are not worth a single testicle.' ${ }^{43}$

The criticism against the kinship system and the revelation of the true status of women in peasant families reflected in post-1975 Vietnamese literature mark a new change in the representation of peasant women. In the wartime literature, writers never described the concrete problems of peasant women. Some writers, such as Nguyen The Phuong, Ngo Ngoc Boi and $\mathrm{Vu}$ Thi Thuong, mentioned that the problems of peasant women were mainly caused by conservative ideas, but they simply concluded that these problems would be soon resolved when more women were promoted to take charge in the political administration, as discussed earlier in this article. However, the short stories and novels written in the post-1975 period confirm that the introduction of Socialist largescale industry and promotion of women's roles in the agricultural co-operatives could not completely change the patriarchal view about women and permanently elevate their social status in village community. This is because the problems of peasant women are deeply rooted in the family.

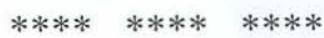

Some conclusions can be drawn from

${ }^{43}$ In a study of the Vietnamese family, Pham Van Bich reveals that peasant women, not only upper-class women, are also influenced by Confucian teachings, especially their 'ideas of gender hierarchy'. For more information, see Pham Van Bich. The Vietnamese Family in Change: The Case of the Red River Delta. P. 245. this study of the representation of peasant women in Vietnamese literature. First, the way in which peasant women are portrayed is closely related to the political agenda. In the period between 1930 and 1945, the victimisation of peasant women was used as a tool to criticise the colonial administration. In the $1945-75$ period, literature took part in mobilising the force of peasant women in the building of a socialist nation. Post-1975 literature reflected the failure of the Communist government and its Socialist ideology to eradicate the residue of the old values in the countryside, including the patriarchal concepts and the kinship system. Thus, it can be said that the construction of peasant women in Vietnamese literature is not only gender-based, but also politically bound.

Secondly, the stereotypes of peasant women changed through the transition of the socio-political context from war to peace. The wartime literature emphasises masculine qualities, whereas the post-1975 literature tries to revitalise feminine characteristics. According to the literary texts, after the war ended, women were expected to return to a home-making role rather than continuing with their social and political activities. This is just another way to reinforce patriarchal standards imposed on women.

Thirdly, the representation of peasant women in Vietnamese literature is also interrelated to the issue of social class. It can be observed that the problems of peasant women are more emphasised in literary works by male writers originating from peasant backgrounds than by 
female writers from the middle-class. It is noticeable that the works written by female writers in the post-war period respond to the problems that concerned middle-class women in urban areas.

The Vietnamese literary scene continues to be dominated by male writers. Female writers are few and remain in the background. That is why, in maleproduced texts, the construction of peasant women is never free from a gender-biased vision and the stereotypes of peasant women are entirely shaped by men's ideas and experiences. The humanist concept of male writers may enable the exposure of patriarchal influences and the sufferings of peasant women in literature, but an attempt to liberate women is not yet evident in the male-dominated literary world. Although the stories of Vietnamese peasant women are the inspiration for many literary works, peasant women do not write. It is unfortunate that peasant women cannot represent themselves. 